DOI $10.31489 / 2020 \mathrm{Ec} 1 / 6-15$

JEL: D21, L20, M40

UDC: 334.025

\author{
S.B. Baibossynov ${ }^{1}$, K.A. Nevmatulina ${ }^{2}$, S.S. Shakeyev ${ }^{3}$ \\ ${ }^{1}$ Branch of the Academy of Public Administration under the President \\ of the Republic of Kazakhstan in the Karaganda region, Kazakhstan \\ ${ }^{2}$ Karaganda economic university of Kazpotrebsoyuz, Kazakhstan \\ ${ }^{3}$ E.A. Buketov Karaganda state university, Kazakhstan \\ ${ }^{1}$ ser_08031942@mail.ru, ${ }^{2}$ carisha_07@mail.ru, ${ }^{3}$ sayan.79@mail.ru \\ ${ }^{1}$ https://orcid.org/0000-0002-3881-454, ${ }^{2}$ https://orcid.org/0000-0003-0839-9071, \\ ${ }^{3}$ https://orcid.org/ 0000-0001-6119-1777 \\ ${ }^{1}$ Scopus AuthorID: 56015456600, ${ }^{2}$ Scopus AuthorID: 55857418100, ${ }^{3}$ Scopus AuthorID: 57196348663
}

\title{
Ways of optimization and cost reduction of the enterprise
}

\begin{abstract}
Object: Optimization and cost reduction of the enterprise as a type of activity are in the process of their formation and is manifested primarily in the abundance of models of both local processes and the development of "global" strategies.

Methods: The analysis of activity of the enterprises of various spheres shows that, despite abundance of publications on optimization of expenses, it is seldom when enterprise can show a sample of the organization of this process. Contrariwise, the number of unprofitable enterprises indicates that there are serious problems in the organization of the system of optimization and cost reduction. The article uses content analysis.

Findings: The strategy of cost optimization sets such tasks as identifying areas of cost reduction as a factor in improving economic performance, determining ways to reduce costs for the main stages of the economic cycle of the product, as well as the calculation of costs for the operating segments and production units of the enterprise.

Conclusions: Taking into account that article is devoted to the optimization and, as a consequence, to cost reduction in the enterprise, the author substantiates the necessity for the optimization process and reveals the basic principles of cost optimization in the enterprise. Special attention is paid to the methods and methods of cost optimization, their advantages and disadvantages are revealed.
\end{abstract}

Keywords: cost optimization, enterprise, cost reduction measures, cost management, cost analysis.

\section{Introduction}

In the context of developing market relations with the instability of the external environment in enterprises there is a need for effective management to minimize their own costs. The problems of reducing costs in the enterprise, finding ways to solve them are complex and interesting issues of the modern economy of the enterprise.

The purpose of any enterprise is to achieve an economic effect of the activity, which can be expressed depending on the aims of the establishment and activities both through profit and through the achievement of any social, environmental and other improvements. But only by comprehensively analyzing the costs of the organization and correctly determining the reserves for their reduction, it is possible to achieve this goal.

Cost optimization is the process of finding and implementing the most effective way to manage finances. There are no businesses, firms or enterprises can exist without costs. It is no secret that the costs should be useful: the company is profitable when the money spent leads to profit. In such cases, cost optimization helps to increase profitability, avoid economic problems and keep the company even in crisis times (Dan Steinhoff, John F. Burgess,1993).

Every enterprise can be represented in the form of a chain of processes. It receives some resources, which, passing this sequence, are modified, acquiring the form of a product or service at the output. At the same time, each link in the chain is a specific function that requires certain resources to perform and has its own cost. Based on this understanding, both cost reduction and optimization should begin with an analysis of business processes.

Hypothesis. Costs reducing, optimization and identifying their cost compliance solve the problem of reducing the resources spent and increasing labor productivity. 


\section{Literature Rewiew}

The problems of management and cost optimization dedicated to the work of many foreign scientists, namely, I.A. Basmanov， S.P. Gavrilovskaya， K. Druri， D. Doyle， H. Horngren， D. Foster， G. Cokins, A.D. Sheremet, N.G. Danilochkina, S.A. Nikolaeva, V.E. Kerimov and others.

I.A. Basmanov believes that "... optimization of production costs and their reduction are independent, separate from each other concepts that are inherent in various both subjects of study and methods of knowledge".

S.P. Gavrilovskaya in his work justifies the need to form a card of profitability of products and recommendations for multi-factor cost optimization in order to improve cost management.

In his book "Management accounting for business solutions" K. Drury one of the four sections is devoted to cost management. In this section, along with the already known approaches to cost management, the author identifies several new ones.

A significant place in the work of D. Doyle is given to the outsourcing mechanism, which is considered as one of the effective tools for optimization of internal expenses (Doyle D., 2002).

Scientists Ch.T. Horngren, J. Foster outline the features of profit optimization by assigning deviations in the standard-cost system to the cost of the period (Horngren Ch., Foster G., Datar S., 2005).

Gary Kokins identified the need of effective combining elements of different systems of cost management and the achievement of a synergy effect (Cokins Gary, 2013).

Other famous scientists also support an integrated cost management system. So, A.D. Sheremet notes that at the moment "there is an objective integration of management methods into a single management accounting system" (Sheremet A.D., 2004). An overview of the possible combinations of effective cost management methods and tools can be found in H.D. Danilochkina (Danilochkina N.G., 1999). S.A. Nikolaeva, V.E. Kerimov adhere to the integrated approach in the construction of cost management systems.

At the same time, the study of the works of these authors showed that to date, the main methodological and applied problems of developing methods of sustainability through cost optimization for effective management decisions were beyond the scope of system research. And already existing scientific developments are not adapted to the practice of enterprises, which undoubtedly has a huge impact on the development of the economic environment as a whole.

\section{Methods}

The problem of cost optimization is very relevant in contemporary economic conditions, as its solution allows each individual company to survive in a tough market competition, to build a strong company that will have a good economic potential. This is due to the fact that the achievement of high results of the enterprise and profit maximization cannot be achieved without effective cost management. At the same time, today there is a lack of methodological base, on the basis of which it would be possible to assess the impact of costs on the condition of the enterprise, due to the fact that domestic methods of evaluation allow to identify the impact of costs on sustainability only on the basis of financial statements (formalized data), while informal data (quality of management, organizational structure, level of management and production personnel of the enterprise, the availability of budgeting system) are not taken into account, and, accordingly, do not influence on the overall assessment of the stability of the enterprise.

The purpose of any optimization is not only costs reduction, but increasing the efficiency of the enterprise. The concept of "cost reduction" is inseparable from the concept of "cost effectiveness". To develop cost-cutting measures, it is necessary to understand how costs are generated in each direction, how business processes are designed, and what should be done to reduce them. For this purpose, certain cost reduction plans are drawn up, which usually include those cost items that need to be reduced (Denisov D.V., 2019).

The methodological basis of the research is the dialectical method, General scientific and special methods were also used.

\section{Results}

Cost optimization is the main element of the cost management system. If enterprise doesn't optimize costs, it simply won't be able to survive in a rapidly changing environment. The effectiveness of cost reduction depends on how revenue and expenditure are recorded. Management activities carried out in conditions of economic downturn should be close to the approaches typical for anti-crisis management, strategic management, project management and risk management at the same time. 
Cost optimization is the main element of the cost management system. If the company doesn't optimize costs it simply will not be able to survive in a rapidly changing environment. The effectiveness of cost reduction depends on how revenue and expenditure are recorded (John K. Shank, Vijay Govindarajan, 1989).

In practice, there are three principles that should be followed in order to avoid unnecessary spending:

1) planning;

2) control;

3) discipline.

Planning. A very common mistake in the planning is control of only expenses, without regard to income. It is necessary to control not only the spending of available money, but also to pay special attention to the sources of income. Otherwise, the company faces a shortage of funds and the need to attract loans, which can eventually lead to bankruptcy. Incoming and outgoing cash flows should be planned in advance (Kotlyarov, S.A., 2002). Cost optimization will be more successful if the Manager always has the planned amount of income and expenses for the next month, quarter, year. In the short term, some investments may seem costly, but they will yield greater benefits in the future.

Control. The head of the enterprise should always receive objective information about the state of the business. Cost control is impossible without the latter. At large enterprises, it is advisable to create a Department to work on cost reduction and optimization, which studies the factors affecting the costs, checks the compliance of technical processes in the enterprise with the established standards, finds out the causes of failures, monitors the presence of failures during the shipment or receipt of goods, reveals the packing of the warehouse. After collecting information about all costs, its analysis is carried out, then - the reduction and optimization of the identified costs. The head of the enterprise plans and approves a program to reduce costs, which includes activities of various sizes: from changing suppliers to improving the efficiency of work with customers (Mayer E., 2013).

Discipline. Further, the strategy chosen and approved by the head is reflected in the budget of the enterprise, and to deviate from it only in exceptional cases. Compliance with the rules is assessed by the financial services, which monitor the validity of costs and prevent unnecessary spending. Decisions on the cost of funds should be made by only a few responsible persons.

Optimization of costs does not mean taking actions to the detriment of the interests of the enterprise. The task of reducing costs should be solved in the best way, by comparing costs and revenues with each other. The issue can be solved in several directions:

1. Cost reduction from internal resources (direct reduction). Such actions can include increasing productivity, reducing material costs, reducing management costs, as well as reducing the staff of the enterprise.

2. Reduction of production costs (relative reduction). This can be achieved by increasing production. In this case, on the producing of one detail will be spent less money.

3. Formation of the offer due to the conducted marketing research. In this case, the growth of the volume of purchases by customers is stimulated and an influx of new customers is formed.

4. Formation of the strict financial discipline. In this case, a limited number of people may give an "approval" for expenses.

The Manager can use three possible ways of optimization in his optimization activity of costs of the enterprise:

1. Systematic cost reduction, which involves a gradual (over several years) cost reduction. This cost reduction is connected with the improvement of three areas of activity:

- investment. Investments that are invested in the purchase of new equipment and the introduction of new modern technologies are necessary for the enterprise to solve problems and improve production. Investment projects should undergo a serious selection, due to the fact that such investment projects spend a large amount of money. This requires full justification of the feasibility of such investment. The head of the company must clearly and accurately understand whether his costs will pay off in the future, and what will be the profit (Nooraie Vahid, Parast S.A., 2016).

- purchases. Purchases are the main share of the company's costs. The process of procurement management is to find more profitable suppliers, since it is from vendor depends on how effectively they meet the needs in raw materials, etc. (Umirzakova D.K., Megis N., 2017).

- production process. In some enterprises, the technology of "lean production" is used to effectively costs reduce. All costs are estimated from the customer's point of view and the company has to either get rid of those processes that are not approved by the buyer, or reduce the cost on them (Nidhi, M.B., Anil, B.B., 2011). 
All these three processes form the most significant share of the company's costs, and therefore managers try to reduce them gradually, so that they have less impact on the final activity of the enterprise, i.e. profit.

2. Rapid reduction requires work to reduce costs within weeks or months. Rapid cost reduction involves reducing fixed and variable costs of the enterprise, that is, on this way to reduce costs, there is a reduction in the cost of raw materials and materials. The increase in the cost of consumption of materials (basic and auxiliary) is due to the rise in the cost of purchased raw materials, the rise in the cost of auxiliary materials and the growth of utilities.

The most effective solution to reduce costs is to revise contracts with suppliers. The company begins to look for companies that can offer lower prices for raw materials and can also provide deferrals on payments (Vasina A., 2019). To reduce such costs as the costs on materials and raw materials, it is possible to carry out the following activities:

- review the terms of contracts with existing suppliers;

- search for new suppliers;

- search for high-quality but inexpensive components in the production;

- help suppliers to reduce their costs;

- procurement of materials, together with another buyer from the same supplier;

- independent production of necessary materials;

- introduction of resource-saving technological processes that contribute saving on the cost of raw materials (Dutta, P.A., Mishra, A.A., Khandelwal, S.B., Katthawala, I.B., 2020).

In parallel with the search process, there is a reduction in the number of overhead costs: the cost of electricity, transport, heating, etc. the cost of electricity can be reduced in the control of energy consumption by limiting the lighting of the room in the dark, if it does not interfere with the production process, the transition to economical methods of lighting and equipment. With regard to transport costs, the number of service vehicles should be reduced, and fuel consumption for these vehicles should be more closely monitored. Reducing heating costs, for example, can be done by installing steam generators(Jae K. Shim, Joel G. Siegel, 2000).

Another way is to reduce the wage fund. A more acceptable way to reduce costs is to reduce wages, but in order to prevent employees from being unwilling to work, it is necessary to provide them with social benefits: free food, extended health insurance, etc. (Lebedev V.G., Drozdova T.G., Kustarev V.P., 2010). To solve the problem of activation of valuation processes in enterprises the most effective option of rationing costs based on existing methods are developed:

1) Microelement regulation - is the regulation of labor with the help of pre-designed microelements of the labor process. The essence of microelement rationing is that the most complex and diverse in nature labor actions are combinations of simple or primary elements.

2) Experimental and analytical regulation is carried out on the basis of the study of labor processes directly in production conditions.

3) Settlement and analytical regulation - labor standards are established on the basis of standard of the mode of operation of machines and time standards for the implementation of individual elements of the operation, developed differentiated for different organizational and technical conditions on the basis of numerous observations.

Application of typical standards (norms) assumes systematization of conditions of performance of each labor process on the basis of carrying out their certification.

3. Express reduction is a reduction that can be carried out within a few days. With this reduction in costs, it is necessary as soon as possible to stop paying for some items and to determine the cost of significance. All costs are divided into:

- high priority (payment of wages to employees, purchase of raw materials for production). Such costs are necessary for the enterprise to continue its activities.

- priority (mobile payment, advertising). If company stops payments under this article, the work of the company will go astray.

- acceptable (benefits for employees, payment of sanatorium treatment to staff). If the company does not have free funds, these payments can be suspended, but it is preferable to keep them.

- unnecessary (payment for a private flight for the head of the company). Cancellation of such expenses will not adversely affect the company's operations. 
When choosing an express cost reduction on the first place payments stop on the "unnecessary" article and sharply limit the permissible. High-priority and priority costs should not be reduced, because when they are reduced, there is a danger of stopping the operating activity and harming the normal conduct of business.

3. Express reduction is a reduction that can be carried out within a few days. With such reduction in costs, it is necessary as soon as possible to stop paying for some items and to determine the cost of significance. They can be high-priority, priority, acceptable and unnecessary. Of these costs, it is necessary to abandon unnecessary costs, because they do not bear any profit to the enterprise (payment for rest to the head of the enterprise). Further, it is necessary to reduce the financing of eligible costs (payment for sanatorium treatment of employees). High-priority and priority costs should not be reduced, because when they are reduced, there is a danger of stopping operating activities and harming the normal conduct of business.

One of possible ways to reduce costs is are models to improve their efficiency. These models have both advantages and disadvantages. There are three main efficiency models:

1) "net" cost reduction is cost reduction by getting rid of unproductive costs. The main savings are due to fixed costs (Erdavletova F.K., 2016);

2) "intensification" of costs - there is even a slight increase in costs, but more significantly increases and increases revenue. As a rule, this occurs when new equipment is introduced, technologies that increase the productivity of the equipment, and consequently, revenue;

3) "fixing " costs - when the revenue increases costs are not increased. As a rule, this is either an increase in the price of products, or an equivalent increasing of productive costs and a decrease in unproductive (Gagarski V., 2019)

The directions of cost reduction programs are very diverse. These include:

- introduction of new more economical technologies(Drury C., 2006).

- application of more modern organizational concepts;

- outsourcing - refusal of own production of some products or services and transition to purchase from third parties;

- in contrast to outsourcing, the transition from procurement of a number of products and services on the side to their own production;

- invention and innovation.

The successful implementation of the cost reduction program and the creation of a mechanism for regular cost optimization will allow the company to improve business efficiency or use low product prices as one of the key advantages in the competition.

In fact, the company has many different activities, costs, it interacts with a large number of suppliers, partners, customers, it employs staff with certain qualifications, so it is advisable not to follow a particular model of cost reduction, and apply them to the situation that has developed in the enterprise. And each company through certain losses and errors determines the most effective methods of optimizing the cost of the enterprise.

When drawing up a plan of measures to optimize costs, the Manager needs to remember that the situational solution of the problem is not always the best choice. By following the optimization rules, company can achieve the maximum effect with the least tolls:

1. Costs do not always need to be reduced; most often they need to be effectively managed, that is, to reduce the total costs you need to increase the amount of costs in any particular direction.

2. Costs are minimized for best results. The efficiency rule says that one unit of cost must provide the maximum result.

3. The desire to minimize costs is not always useful. It may be optimal to slightly reduce costs and maintain them at the required level.

4. Optimization of budget expenditures is impossible without financial investments.

5. Cost optimization should be ongoing. New items of expenditure affect the profit of the enterprise, so cost tracking should be a mandatory task, reporting on the implementation of which is submitted to the management of the enterprise.

Thus, the optimization of income and expenses are two procedures that go hand in hand. Uncontrolled costs will not bring income to the enterprise, and profit growth is directly related to the cost control.

All optimization processes should start from the head of the enterprise who should carry out any optimization actions, starting with himself, and put an equal sign between the reputation of the enterprise and personal reputation. 
Of course, all employees of the enterprise and outsourcers can be forced to compensate, to fine or to collect a penalty for losses, for errors and shortcomings, but in general for the mistakes of the head of the enterprise he has to pay by himself.

As an application tool to optimize costs and expenses arising from errors of project managers, company can use:

- the classical method of calculation of penalties, allowing to estimate the costs of erroneous actions in real terms;

- one of the methods of calculation of reserves and extensive nature (ER, Extensive Resources), where ER is the value of the unconditional loss the fault of the head, multiplied by the actual resource allocation.

Further, in case of unfavorable conditions, managers need to pay special attention directly to business processes, due to the fact that the average period of solving the problem by managers is several times greater than the time spent by enterprise managers to solve the same tasks.

Two heads are much easier can find the points of intersection of interests, rather than Director and Manager. This approach saves time and money, allows to create a long-term picture of cooperation and is based on greater trust. Therefore, the leaders of one company are trying to come up with a proposal for cooperation to the head of another company and discuss the details of cooperation directly with him, especially in solving such problems and the occurrence of such conditions as:

- establishment of business contacts in the organization of new business;

- project implementation;

- resolution of important and urgent issues;

- occurrence of unfavorable conditions for one of the parties to the agreement;

- interaction with partners and key clients in crisis.

As a rule, the Director sees the prospect of development of the enterprise in advance and his main task is to ensure the management of end - to-end processes. In practice, there are eight keys, end-to-end business processes:

1) customer relationship management;

2) consumer service management;

3) demand management;

4) execution of orders;

5) material flow control;

6) procurement management;

7) product development, value creation;

8) management of recurrent material flows.

Unlike conventional budgeting, crisis management involves managing end-to-end processes, giving not only a complete picture of the state of affairs, but also an idea of the dynamics of changes in key parameters. This is what allows you to make quick optimization decisions in the process, not on the basis of the activity.

Often, business leaders in establishing business contacts and decision-making are often guided by personal preferences and dislikes. However, it is necessary to adhere to a realistic view of the organization of work and the state of affairs, as well as objectively assess the business qualities of employees and partners. However, establishment of relationships on this basis does not give any special guarantees, especially in the event of adverse conditions. Moreover, interaction with partners is often complicated by the desire of entrepreneurs to conclude various "gentlemen's agreements". Management of enterprises and projects requires the ability not to take wishful thinking, to establish contacts, guided by the interests of the company, not personal sympathies, to reasonably determine the goals and evaluate the results.

Setting the task to optimize costs, it is necessary to assess the structure of the processes taking place in the enterprise, for their compliance with time-tested approaches, methods and disciplines, including:

- analysis of economic activity of the enterprise;

- marketing analysis;

- working capital management (including inventory management). Unfortunately, the incompetence of managers in the management of working capital in the activities of many enterprises leads to chaotic or illconceived, undocumented distribution of funds and resources. This is a fairly common cause of the crisis situation within the enterprise.

Circulating capital management is a set of tasks that ensure the process of transition (strategy of transfer) of the enterprise from the current state to the planned one. The main indicators of efficiency of use of current 
assets are: the value of current assets and equity, the structure of working capital, the turnover of individual elements of working capital, the duration of the financial cycle, the return on working capital before tax.

Knowing that there is a certain dependence of working capital and profit, experienced managers constantly monitor the dynamics of profit changes depending on the size of working capital, thus being able to make timely decisions on the launch of new projects and the implementation of appropriate investments.

The main methods of "getting rid of ballast" include:

- necessity to assess reserves of an extensive nature, when the amount of additional attraction or the amount of unconditional loss of resources is known;

- analysis of logistic value. Carrying out this analysis gives an idea of what the company costs content (storage, accounting, etc.) ballast;

- structuring of inventories;

- optimization of inventories. Illiquid goods can be used as a "loss-making leader", i.e. goods sold at a loss, to attract buyers;

- assessment of profile and non-core parts of the enterprise. Focusing on the core of the enterprise and transferring peripheral aspects to subcontractors, increases efficiency and effectiveness, allowing both management and workers to deal with the most important elements and not to waste effort and experience on less important aspects.

\section{Discussion}

The head of the enterprise in his work should know the profitability and control the dynamics of its change. The level of profitability required by the investor or co-owner of the enterprise's equity capital can be considered as a necessary level of profitability for the enterprise. This level depends on the level of profitability of competing investments and the ratio of risk investments in own projects of the enterprise and alternative products of the stock market. It is obvious that with frequently changing prices, rates, quotes, etc. it is necessary to ensure constant monitoring of profits and monitor the dynamics of changes in profitability, for example, by tracking indicators such as:

- return on current assets;

- return on net equity;

- the total profitability of the enterprise (before tax).

Inadequate market pricing can lead to partial or complete "paralysis" of the enterprise. Pricing strategies and methods are one of the most important and voluminous areas of cost management.

In addition to the above, a business Manager who wants to optimize costs should have key information about value chains and supply chains. For the present reality it is typical that the supply chain management deals the Director or authorized person, or no one engaged.

A precise knowledge of the operations occurring along the entire length of the supply chain and defining relationships between them enables managers not only to focus on planning for future expenses and their optimization, but also on the increase of income and increase the share of market presence.

The Manager should clearly assess the opportunities, risks, advantages and disadvantages of integration with other partners, as well as develop joint solutions to overcome difficulties and neutralize system competitors. This approach will allow not to be under pressure of third companies, but to successfully use the coincidence of interests in the work, turning it into a center of profit generation.

\section{Conclusions.}

Thus, analyzing all of the above, cost optimization of the company can be performed in the following ways:

1. Saving on raw materials, the main rule of which is to reduce costs not at the expense of quality. The ideal solution is not to reduce the quality of materials, but to revise contracts with suppliers, search for more profitable offers.

2. Analysis and cost reduction for electricity, transport, telecommunications. The transport workshop can be outsourced if the main activity of the company is not related to the provision of transport services. It is possible to reduce energy costs in traditional ways: the transition to energy-saving equipment, flow control.

3. Optimization of the wage fund, reduction of staff. Part of the functions of the company is sometimes more profitable to give them to outsource. Not all staff is beneficial to leave in the enterprise: for example, a person for cleaning only $1-2$ times a week. 
4. And, the so-called universal ways of optimization of the company's costs. At any enterprise, there is opportunity to optimize or reduce the following costs:

1) the costs of maintaining high status visibility (unreasonably expensive office, elegant car for the head of the company, expensive office phones);

2) production losses (reduction of fuel, raw materials, electricity);

3) the hidden, implicit costs, eliminating the costs of missed opportunities (more rational allocation of machinery in manufacturing, use of human resources).

The result of the optimization of unnecessary costs will be the output of the efficiency of the enterprise to a new level.

\section{References}

Cokins, G. (2013). Top 7 trends in management accounting. Strategic Finance, 12, 21-29. Retreived from: https://sfmagazine.com/wp-content/uploads/sfarchive/2013/12/Top-7-Trends-in-Management-Accounting.pdf

Vasina, A. (2019). Proekty snizhenija zatrat: opisanie al'ternativi rascheta jekonomicheskogo jeffekta [Cost reduction projects: description of alternatives and calculation of economic effect]. www.alt-invest.ru. Retreived from: https://www.alt-invest.ru/index.php/ru/biblioteka/tematicheskie-stati/analiz-investitsionnykhproektov/1578-proektysnizheniya-zatrat-opisanie-alternativ-i-raschet-ekonomicheskogo-effekta.

Danilochkina, N.G. (1999). Kontrolling kak instrument upravleniia predpriiatiem [Controlling as an enterprise management tool]. Moscow: Audit, Iuniti, $279 \mathrm{p}$.

Denisov, D.V. (2019). Analiz syshestvuyushih podhodov k sovershenstvovaniyu sistemi upravleniya zatratami [Analysis of existing approaches to improving the cost management system]. biznes-planirovanie.ru. Retreived from: $\mathrm{http}: / /$ biznes-planirovanie.ru/analiz_sushestvuiushih_podhodov_k_sovershenstvovaniiu_sistemy_upravleniia_zatrata mi.

Doyle, D. (2002). Cost Control. A Strategic Guide. CIMA Publishing.

Drury, C. (2006). Cost and Management Accounting. Thomson Learning.

Dutta, P.A., Mishra, A.A., Khandelwal, S.B. \& Katthawala, I.B. (2020). A multiobjective optimization model for sustainable reverse logistics in Indian E-commerce market. Journal of Cleaner Production, 249.

Erdavletova, F.K. (2016). Funkcional'naja kal'kuljacija sebestoimosti (metod - ABC) kak mehanizm optimizacii proizvodstvennyh zatrat [Functional cost calculation (method - $\mathrm{ABC}$ ) as a mechanism for optimizing production costs]. Vestnik Karagandinskogo universiteta. Seriya Ekonomika - Bulletin of Karaganda State University. Economy series, $3(83), 147-155$.

Gagarski, V (2019). Sokrashenie izderzhek kompanii [Reducing company costs]. www.gagarskiy.narod.ru. Retreived from: http://gagarskiy.narod.ru

Horngren, Ch., Foster, G. \& Datar, S. (2005). Cost accounting. (10-th edition), Prentice Hall.

Kotlyarov, S.A. (2002). Upravlenie zatratami [Cost Management]. Saint Petersburg: Peter.

Lebedev, V.G., Drozdova, T.G., \& Kustarev, V.P. Upravlenie zatratami na predpriyatii [Cost management in the enterprise]. Saint Petersburg: Business-press.

Mayer, E. (1993). Controlling the system thinking and management. Moscow: Finance and statistics.

Nidhi, M.B. \& Anil, B.B. (2011). A cost optimisation strategy for a single warehouse multi-distributor vehicle routing system in stochastic scenario. International Journal of Logistics Systems and Management, 10, 110-121.

Nooraie, V. \& Parast, S.A. Mitigating supply chain disruptions through the assessment of trade-offs among risks, costs and investments in capabilities. International Journal of Production Economics, 171, 8-21.

Shank, J.K. \& Govindarajan V. (1989). Strategic cost analysis: the evolution from managerial to strategic accounting. Richard D. Irwin

Shim, J.K. \& Siegel, J.G. (2000). Modern Cost Management and Analysis. Paperback.

Steinhoff, D. \& Burgess, J.F. (1993). Small Business Management Fundamentals. McGraw-Hill Companies

Umirzakova, D.K., Megits, N. (2017). Teoreticheskie podhody k klassifikacii funkcionirovanija cepejpostavok [Theoretical approaches to classifying the functioning of supply chains]. Vestnik Karagandinskogo universiteta. Seriya Ekonomika - Bulletin of the Karaganda University. Economy series, 4(88), 205-215

Sheremet, A.D. (2004). Upravlencheskii uchet [Management account]. Moscow: Izdatelskii dom FBK PRESS. 


\section{С.Б. Байбосынов, К.А. Невматулина, С.С. Шакеев}

\section{Кәсіпорынды оңтайландыру және шығындарды төмендету жолдары}

\section{Аннотация}

Maқcambl: кәсіпорынды оңтайландыру және шығындарды төмендету қызметі ретінде оның қалыптасу үдерісін және ең алдымен, жергілікті үдерістердің үлгілері мен «жаһандық» стратегияларды әзірлеу.

Әдісі: әртүрлі салалардағы кәсіпорындардың қызметін талдау, шығындарды оңтайландыру бойынша жарияланымдардың көп болуына қарамастан, компания бұл процесті ұйымдастырудың үлгісін сирек көрсете алады. Керісінше, зиянды кәсіпорындардың саны шығынды азайту және оңтайландыру жүйесін ұйымдастыруда елеулі проблемалар бар екенін көрсетеді. Мақалада контент талдау жүргізілген.

Kорытынды: шығындарды оңтайландыру стратегиясы шығынды экономикалық тиімділікті арттыру факторы ретінде анықтауға, өнімнің бизнес циклінің негізгі кезеңдеріне жұмсалатын шығындарды қысқарту жолдарын анықтайтын және кәсіпорынның өндірістік сегменттері мен өндірістік бөлімшелеріне шығындарды есептеуге арналған міндеттерді белгілейді.

Тұжырымдама: мақала оңтайландыру мәселелеріне және соның салдарынан кәсіпорындағы шығындарды төмендету мәселелеріне арналғанын ескере отырып, авторлар оңтайландыру процесінің қажеттілігін негіздейді және кәсіпорындағы шығындарды оңтайландырудың негізгі принциптерін ашады. Шығындарды оңтайландыру әдістері мен тәсілдеріне ерекше көңіл бөлінген, олардың артықшылықтары мен кемшіліктері анықталған.

Кілm сөздер: шығындарды оңтайландыру, кәсіпорын, кәсіпорынның шығынын төмендету іс-шарасы, шығындарды басқару, шығындарды талдау.

\section{С.Б. Байбосынов, К.А. Невматулина, С.С. Шакеев}

\section{Пути оптимизации и снижения затрат на предприятии}

\section{Аннотация}

Цель: оптимизация и снижение затрат предприятия как вид деятельности находятся в процессе своего становления и проявляются, прежде всего, в изобилии моделей как локальных процессов, так и разработки “глобальных" стратегий.

Memodbl: анализ деятельности предприятий различных сфер показывает, что, несмотря на обилие публикаций по оптимизации затрат, редко, какое предприятие может продемонстрировать образец организации этого процесса. Напротив, количество убыточных предприятий свидетельствует о том, что существуют серьезные проблемы в организации системы оптимизации и снижения затрат. В статье использован контент-анализ.

Результаты: стратегия оптимизации затрат показала направления снижения затрат как факторов повышения экономических результатов деятельности, определение способов снижения затрат по основным этапам экономического цикла продукта, а также расчет затрат по операционным сегментам и производственным подразделениям предприятия.

Bblвoдbl: учитывая, что статья посвящена вопросам оптимизации и, как следствие, снижения затрат на предприятии, авторы обосновывают необходимость процесса оптимизации и раскрывают основные принципы оптимизации затрат на предприятии. Особое внимание уделяется методам и способам оптимизации затрат, выявляются их преимущества и недостатки.

Ключевые слова: оптимизация затрат, предприятие, мероприятия по снижению затрат, управление затратами, анализ затрат.

\section{References}

Steinhoff Dan. Small Business Management Fundamentals / Steinhoff Dan, Burgess John F. — McGraw-Hill Companies, 1993. $-576 \mathrm{p}$.

Денисов Д.В. Анализ существующих подходов к совершенствованию системы управления затратами / Д.В. Денисов // biznes-planirovanie.ru. - (http://biznes-planirovanie.ru/analiz_sushestvuiushih_podhodov_k_ sovershenstvovaniiu_sistemy_upravleniia_zatratami.

Doyle D. Cost Control. A Strategic Guide / D. Doyle. - CIMA Publishing, 2002. — 220 p.

Horngren Ch. Cost accounting / Ch. Horngren, G. Foster, S. Datar. — 10-th edition, Prentice Hall, 2005. — 898 p.

Cokins, G. Top 7 trends in management accounting / G. Cokins // Strategic Finance. — 2013. — № 12. — P. 21-29. https://sfmagazine.com/wp-content/uploads/sfarchive/2013/12/Top-7-Trends-in-Management-Accounting.pdf 
Шеремет А.Д. Управленческий учет: учеб. пос. для вузов. - 2-е изд. / А.Д. Шеремет. - М.: Изд. дом “ФБКПРЕСС", 2004. — 510 с.

Данилочкина Н.Г. Контроллинг как инструмент управления предприятием / Н.Г. Данилочкина. - М.: Аудит; Юнити, 1999. - 279 с.

Shank J.K. Strategic cost analysis: the evolution from managerial to strategic accounting / J.K. Shank, V. Govindarajan. — Richard D. Irwin, 1989. - 161 p.

Котляров С.А. Управление затратами: учеб. пос. / С.А. Котляров. - СПб.: Питер, 2002. — 159 с.

Mayer E. Controlling the system thinking and management / E. Mayer, 1993. — $96 \mathrm{p}$.

Nooraie V., Mitigating supply chain disruptions through the assessment of trade-offs among risks, costs and investments in capabilities [Текст] / V. Nooraie, S.A. Parast // International Journal of Production Economics. — 2016. — Vol. 171. - P. 8-21.

Умирзакова Д.К. Теоретические подходы к классификации функционирования цепей поставок [Текст] / Д.К. Умирзакова, Н. Мегитс // Вестн. Караганд. ун-та. Сер. Экономика. — 2016. — № 4(88). — С. $205-215$.

Nidhi M.B. A cost optimisation strategy for a single warehouse multi-distributor vehicle routing system in stochastic scenario [Текст] / M.B. Nidhi, B.B. Anil // International Journal of Logistics Systems and Management. — 2011. — Vol. 10. - C. 110-121.

Васина А. Проекты снижения затрат: описание альтернатив и расчет экономического эффекта / А. Васина. Режим доступа: https://www.alt-invest.ru/index.php/ru/biblioteka/tematicheskie-stati/analiz-investitsionnykh proektov/1578-proekty-snizheniya-zatrat-opisanie-alternativ-i-raschet-ekonomicheskogo-effekta.

Dutta P.A. A multiobjective optimization model for sustainable reverse logistics in Indian E-commerce market [Tекст] / P.A. Dutta, A.A. Mishra, S.B. Khandelwal, I.B. Katthawala // Journal of Cleaner Production. — 2020. — Vol. 249.

Shim J.K. Modern Cost Management and Analysis / J.K. Shim, J.G. Siegel. — Paperback, 2000. - 346 p.

Лебедев В.Г. Управление затратами на предприятии: учеб. / В.Г. Лебедев, Т.Г. Дроздова, В.П. Кустарев; под общ. ред. Г.А. Краюхина. - СПб.: Изд. дом «Бизнес-пресса», 2010.

Ердавлетова Ф.К. Функциональная калькуляция себестоимости (метод АВС) как механизм оптимизации производственных затрат [Текст] / Ф.К. Ердавлетова // Вестн. Караганд. ун-та. Сер. Экономика. — 2016. — № 3(83). - С. 147-155.

Гагарский В. Сокращение издержек компании / В. Гагарский. - Режим доступа: http:/gagarskiy.narod.ru Drury C. Cost and Management Accounting / C. Drury. — Thomson Learning, 2006. — 596 p. 